\title{
Effects of Bentonite Supplementation on Milk Yield, Milk Composition, Digestibility and Nutritive Values in Holstein Cows
}

\author{
Doaa, E. Saad*; A. A. Osman and S. A. Soliman \\ Department of Animal Production, Faculty of Agriculture, Suez Canal University
}

Received: $17 / 2 / 2021$

\begin{abstract}
The objective of this study was to determine effects of inclusion Bentonite in lactating dairy cows rations on milk yield, milk compositionas well as digestibility, nutritive values and blood urea, alkaline phosphatase, total protein, and liver enzymes. 72 Holstein Frisian cows weighed $650 \pm 5 \mathrm{~kg}$ were randomly divided into 3 groups $(24$ cows in each group) fed 3 rations as follows: ration 1 (control) without additives, ration 2 supplemented with $70 \mathrm{~g}$ Bentonite/cow/day, and ration 3 supplemented with $120 \mathrm{~g}$ Bentonite/cow/day. Experiment lasted for two months. Cows fed on TMR (Total Mixed Ration) which consisted of concentrate feed mixture, corn silage and clover hay. Milk production was recorded. Milk samples were taken, fat, protein and lactose percentages were estimated. Fresh feces samples were collected for five days and dried in oven at $65^{\circ} \mathrm{C}$ for $24 \mathrm{hrs}$, then mixed and then representative samples were taken for chemical analysis. Bentonite added as $70 \mathrm{~g}$ Bentonite/cow/day significantly $(\mathrm{P}<0.05)$ increased Organic Matter(OM), Crud Protein (CP), Crud Fiber (CF) and Nitrogen Free Extract (NFE) digestibility. Bentonite added as $120 \mathrm{~g} / \mathrm{cow} /$ day decreased (OM) digestibility. Milk yield, Fat Corrected Milk (FCM), fat, protein and lactose of lactating cows was increased by adding Bentonite as $70 \mathrm{~g} / \mathrm{cow} /$ day. All values of blood urea, Alkaline phosphatase, AST and ALT enzymes in all groups in this study lied within the normal levels.
\end{abstract}

Keywords: Bentonite, Clay Minerals, Milk Yield, Milk Composition, digestibility

\section{INTRODUCTION}

Natural clays such as Bentonite are crystalline alumino-silicates characterized by their ability to exchange cations without major changes in structure. Clay particles have negative charges along the edges. The negative charges of clays attract positively charged ions or cations such as ammonium (NH4+) and sodium $(\mathrm{Na}+)$. This property suggested that nature clays as Bentonite could be a beneficial feed ingredient. Clay minerals improved feed conversion and adsorption feed mycotoxins and improved production and health of livestock (Nadziakiewicza et al., 2019). El-Saadany et al. (2003) mentioned that chemical composition of Bentonite clay was $53.05 \% \mathrm{SiO}_{2}, 20.26 \% \mathrm{Al}_{2} \mathrm{O}_{3}, 6.74 \%$ $\mathrm{Fe}_{2} \mathrm{O}_{3}, 4.64 \% \mathrm{MgO}, 1.95 \% \mathrm{CaO}, 2.19 \% \mathrm{Na}_{2} \mathrm{O}$ and $1.05 \% \mathrm{~K}_{2} \mathrm{O}$. Ibrahim (2012) mentioned that chemical composition of tafla was $\mathrm{SiO}_{2} 50.05 \%, \mathrm{AlO}_{3} 20.26 \%$, $\mathrm{FeO}_{3} 4.74 \%, \mathrm{CaO} 2.02 \%, \mathrm{MgO} 1.95 \%, \mathrm{Na}_{2} \mathrm{O} 2.19 \%$ and $\mathrm{K} 2 \mathrm{O} 1.05 \%$.Pasha et al., (2007) explained that Bentonite binds aflatoxins present in the feed and consequently prevent aflatoxin toxicity in farm animals. Rindsig et al. (1969) reported that milk production was higher in lactating cows fed high concentrate ration with Bentonite and low level of Bentonite was best than high level. Bentonite clay was used far in history as a traditional healing method for protecting the body from diseases. Because this clay is readily available, it has been a popular and cost-effective way of detoxing the body for quite some time. People have eaten Bentonite clay or put it on their skin for thousands of years. It has been used to clean or protect skin, heal skin infections, treat stomach gas and ease diarrhea. Pasha et al. (2007) explained that Bentonite is a hydrated aluminum silicate of volcanic origin which contained $50-90 \%$ from mineral montmorillonite. Bentonite has a high cation exchange capacity such as $\mathrm{Na}+, \mathrm{K}+, \mathrm{Ca}++$, and $\mathrm{Mg}++$ (Its cation exchange capacity is $80-120 \mathrm{meq} / 100 \mathrm{~g}$ ).

*Corresponding author e-mail: doaaessam155@gmail.com
The objective of this work was to study the effect of adding Bentonite in the total mixed rations (TMR) on performance of high yielding lactating cows.

\section{MATERIALS AND METHODS}

Experiments were conducted at milk station 2, El-Salhia Farm and Laboratories of Animal Production Department at Faculty of Agriculture, Suez Canal University (Ismailia Governorate), Egypt. 72 Holstein Frisian cows weighed $650 \pm 5 \mathrm{~kg}$ were randomly divided into 3 groups (24 cows in each group), fed 3 rations as follows: ration 1 (control) without additives, ration 2 adding $80 \mathrm{~g}$ Bentonite /cow/day, and ration 3 adding $140 \mathrm{~g}$ Bentonite /cow/day. The feed requirements were calculated according to NRC, (2001). TMR was daily offered to animals in two equal portions at $8 \mathrm{am}$ and $4 \mathrm{pm}$. Drinking water was available at all time. The experiment lasted for two months. Milk production was recorded weekly. Milk samples were taken, fat, protein and lactose percentages were estimated. Fresh feces samples were collected for five days and dried in oven at $65^{\circ} \mathrm{C}$ for $24 \mathrm{~h}$ and mixed, then representative samples were taken. Chemical composition of representative samples was determined according to AOAC (1995) procedures. The digestibility was carried out by acid insoluble ash (AIA) as a natural marker according to Van Keulen and Young (1977) for determination DM in feces.

Procedures of determination acid-insoluble Ash (AIA):A $5 \mathrm{~g}$ sample (feed or feces) was placed in ashing crucible, then burned for 6 hours at $600^{\circ} \mathrm{C}$. Ash was transferred to a beaker $(500 \mathrm{ml})$ then $100 \mathrm{ml}$ of $2 \mathrm{~N} \mathrm{HCl}$ were added and boiled for 5 minutes then filtered through Whatman 541 filter paper and washed with hot distilled water. Filter paper was transferred back into crucible then burned for 6 hours at $600^{\circ} \mathrm{C}$. Crucible was placed in a desiccator and weighed for determination of acid insoluble ash (AIA) according to the equation: 
$\%$ acid insoluble ash $($ AIA $)=\frac{(\text { weight of crucible with Ash }- \text { weight of empty crucible })}{\text { Sample dry weight }} \times 100$

Then average daily dried feces were calculated according to the equation:

$$
\text { Average daily dried feces }=\frac{\text { Average daily dried feed intake } \times \% \text { AIA in feed }}{\% \text { AIA in feces }}
$$

Or the dry matter digestibility\% was calculated according to the equation:

$$
\text { Dry matter }(\mathrm{DM}) \text { digestibility }=\frac{\% \text { AIA in feces }-\% \text { AIA in feed }}{\% \text { AIA in feces }} \times 100
$$

Then average dried feces were calculated as follows:

Average daily dried feces $=$ (averaged daily dried feed intake - (averaged daily dried feed intake $\times$ DM digestibility, \%)
From average daily dried feed intake and average daily dried feces, digestion coefficients of OM, CP, CF and E.E were calculated. The NFE was calculated by difference. The Chemical composition of total mixed rations (TMR) as follows:

Table (1): Chemical composition of total mixed rations (TMR) on DM basis

\begin{tabular}{lccc}
\hline Items & Ration 1 (control) & Ration 2 & Ration 3 \\
\hline Dry Matter (DM)\% & 56.38 & 55.36 & 56.37 \\
Organic Matter (OM) & 93.45 & 92.23 & 88.19 \\
Crude Protein (CP) & 8.15 & 8.52 & 9.30 \\
Ether Extract (EE) & 5.22 & 5.57 & 5.65 \\
Crude Fiber (CF) & 11.44 & 12.16 & 11.76 \\
Nitrogen Free & 68.64 & 65.98 & 61.48 \\
Extract(NFE) & 6.55 & 7.77 & 11.81 \\
Ash & & & \\
\hline
\end{tabular}

Ration 1: CFM + corn silage + berseem hay, Ration 2: CFM + corn silage + berseem hay $+70 \mathrm{~g}$ Bentonite/cow/day,

Ration 3: CFM + corn silage + berseem hay $+120 \mathrm{~g}$ Bentonite/cow/day

Blood samples were collected from Jugular vein of animals fed the different rations. Serum was separated by centrifugation of the blood samples at 3000 rpm for 20 minutes and stored at $-20 \mathrm{C}^{\circ}$ until analysis. Serum constituent measurements of urea $(\mathrm{mg} / \mathrm{dl})$, total protein (g/dl), alkaline phosphatase (ALP, units/l), aspartate transferase (AST, units/l) and alanine transferase (ALT, units/l) were calorimetrically determined using commercial kits (Egyptian Company for Biotechnology, S.A.E, and Diamond, D-P, International) as described by Young and Friedman (2001).

\section{Statistical analysis:}

All data were subjected to statistical analysis by using the general linear model procedure. Mean differences were compared using Duncan' multiple range test (Duncan, 1955). Data were analyzed using SPSS prog.

The mathematical model was as the follows:

$$
\mathrm{Yij}=\mu+\mathrm{Ti}+\mathrm{eij}
$$

Where:

Yij = Individual observation .

$\mu=$ The overall mean for the trial under consideration.

$\mathrm{Ti}=$ The effect of the $\mathrm{i}^{\text {th }}$ treatment.

$$
\text { eij = Random residual error. }
$$

\section{RESULTS AND DISCUSSION}

The chemical composition of Bentonite is shown in Table (2) and is nearly similar with data obtained by Kirovski et al. (2015), El-Saadany et al. (2003).

Table (2): Average chemical composition $\%$ of Bentonite

\begin{tabular}{lc} 
Silicon dioxide $\left(\mathrm{SiO}_{2}\right)$ & 52 \\
Aluminum Oxide $\left(\mathrm{Al}_{2} \mathbf{O}_{3}\right)$ & 22 \\
Ferric Oxide $\left(\mathrm{Fe}_{2} \mathbf{O}_{3}\right)$ & 4.25 \\
Magnesium Oxide $(\mathrm{MgO})$ & 1.25 \\
Calcium Oxide $(\mathrm{CaO})$ & 4 \\
Sodium Oxide $\left(\mathrm{Na}_{2} \mathrm{O}\right)$ & 1.25 \\
Potassium Oxide $\left(\mathrm{K}_{2} \mathbf{O}\right)$ & 1.3 \\
\hline
\end{tabular}

Bentonite was added as $70 \mathrm{~g} / \mathrm{cow} /$ day in lactating cow ration (Table 3$)$ and significantly $(\mathrm{P}<0.05)$ increased digestibility of $\mathrm{OM}, \mathrm{CP}, \mathrm{CF}$ and NFE. These results agreed with those obtained by Ghoniem et al. (2018) with lactating buffalos. EE digestibility was not 
affected with Bentonite addition. Adding Bentonite as $120 \mathrm{~g} / \mathrm{cow} /$ day decreased OM digestibility. This is agreed with Fisher and MacKay (1983) who noticed that digestion coefficient of $\mathrm{OM}$ was significantly decreased with Bentonite addition at levels of 0.6 or $1.2 \%$ in lactating cow's rations containing grain mixture and corn silage than no addition of Bentonite. The total digestible nutrients (TDN) of rations 2 was significantly $(\mathrm{P}<0.05)$ higher than that in control and ration 3 . Adding Bentonite as $120 \mathrm{~g} / \mathrm{cow} /$ day significantly $(\mathrm{P}<0.05)$ decreased TDN which disagreed with Ghoniem et al. (2018). Adding Bentonite as $120 \mathrm{~g} /$ cow/day significantly $(\mathrm{P}<0.05)$ increased DCP than other rations.

Table (3): Digestion coefficients and nutritive values (\%) of experimental total mixed rations (TMR) with or without Bentonite addition by lactating cows

\begin{tabular}{lccl}
\hline Items & Ration 1 & Ration 2 & Ration 3 \\
\hline & & Digestion coefficients, \% & \\
\hline Organic Matter (OM) & $75.63 \pm 0.26^{\mathrm{b}}$ & $81.22 \pm 0.27^{\mathrm{a}}$ & $73.74 \pm 0.40^{\mathrm{c}}$ \\
Crude Protein (CP) & $71.25 \pm 0.59^{\mathrm{b}}$ & $71.38 \pm 0.51^{\mathrm{a}}$ & $74.63 \pm 0.48^{\mathrm{b}}$ \\
Ether Extract (EE) & $51.14 \pm 0.45^{\mathrm{b}}$ & $65.68 \pm 0.54^{\mathrm{a}}$ & $65.43 \pm 0.52^{\mathrm{a}}$ \\
Crude Fiber (CF) & $33.25 \pm 0.07$ & $34.07 \pm 0.37$ & $34.4 \pm 0.42^{\mathrm{a}}$ \\
$\begin{array}{l}\text { Nitrogen Free } \\
\text { Extract(NFE) }\end{array}$ & $72.52 \pm 0.57^{\mathrm{b}}$ & $80.48 \pm 0.28^{\mathrm{a}}$ & $72.53 \pm 0.41^{\mathrm{b}}$ \\
\hline & & Nutritive values, \% $^{\mathrm{b}}$ & \\
\hline $\begin{array}{l}\text { Total Digestible Nutrients } \\
\text { (TDN) }\end{array}$ & $65.34 \pm 0.43^{\mathrm{b}}$ & $71.40 \pm 0.36^{\mathrm{a}}$ & $63.60 \pm 0.24^{\mathrm{c}}$ \\
$\begin{array}{l}\text { Digestible Crud Protein } \\
\text { (DCP) }\end{array}$ & $5.81 \pm 0.07^{\mathrm{b}}$ & $6.08 \pm 0.22^{\mathrm{b}}$ & $6.94 \pm 0.11^{\mathrm{a}}$ \\
\hline
\end{tabular}

${ }_{\mathrm{a}, \mathrm{b}, \mathrm{c}}$ means in the same row with different superscripts are significantly different $(\mathrm{P}<0.05)$.

Ration 1: CFM + corn silage + berseem hay, Ration 2: CFM + corn silage + berseem hay + 70g Bentonite/cow/day and Ration 3: $\mathrm{CFM}+$ corn silage + berseem hay $+120 \mathrm{~g}$ Bentonite/cow/day

The milk yield of lactating cows fed ration $2(70 \mathrm{~g}$ Bentonite/cow/day) was higher than that in control. These results agreed with those obtained by Ghoniem et al. (2018). The highest milk yield was recorded with ration 2 which increased by $10.11 \%$ than that in control as shown in Table (4). The differences of milk fat, protein, and lactose percentages among rations 1 (control), ration 2 and ration 3 were not significant (Table 4). These results agreed with those obtained by Jiang et al. (2018). The yield of milk fat of lactating cows fed ration 2 was higher than that in control, where protein yield of rations 2 was higher than other rations. Furthermore, adding Bentonite $70 \mathrm{~g} / \mathrm{cow} /$ day increased lactose yield.
The feed efficiency and feed conversion of rations 2 were better than control as shown in Table (4). These results were in agreement with Ghoniem et al. (2018) who found that feed efficiency as DM of lactating buffalos fed the ration containing Bentonite was better than that without Bentonite. The economic efficiency of rations 2 was higher than that in control and ration 3 (Table 4). The best economic efficiency was recorded with rations 2 (70 g Bentonite/cow/day). These results were agreed with Ghoniem et al. (2018) who found that economic efficiency was better of lactating buffalos fed Bentonite than control without Bentonite.

Table (4): Milk yield, FCM and Milk components of lactating cows fed experimental total mixed rations (TMR) with or without Bentonite addition

\begin{tabular}{llll}
\hline Items & Ration1 & Ration2 & Ration3 \\
\hline Milk yield (kg / cow /day) & $29.76 \pm 1.32^{\mathrm{ab}}$ & $32.77 \pm 1.34^{\mathrm{a}}$ & $26.36 \pm 1.67^{\mathrm{b}}$ \\
Difference than control, \% & - & +10.11 & -11.42 \\
milk yield\% from control & 100 & 110.11 & 88.58 \\
$\mathbf{3 . 5 \%}$ FCM yield (kg / cow /day) & $30.09 \pm 0.95^{\mathrm{b}}$ & $33.23 \pm 0.4^{\mathrm{a}}$ & $26.91 \pm 0.76^{\mathrm{c}}$ \\
Fat\%* & $3.57 \pm 0.24$ & $3.59 \pm 0.15$ & $3.63 \pm 0.10$ \\
Protein \%* & $2.67 \pm 0.21$ & $2.72 \pm 0.10$ & $2.71 \pm 0.23$ \\
Lactose\%* & $3.84 \pm 0.03$ & $3.82 \pm 0.03$ & $3.86 \pm 0.05$ \\
Fat yield (kg) & 1.06 & 1.18 & 0.96 \\
Protein yield (kg) & 0.79 & 0.89 & 0.71 \\
Feed efficiency (Kg milk/ Kg DM) & 1.43 & 1.57 & 1.26 \\
Feed conversion (Kg DM /Kg milk) & 0.70 & 0.63 & 0.79 \\
Economic efficiency & 2.31 & 2.54 & 2.04 \\
\hline
\end{tabular}

a,b,c, means in the same row with different superscripts are significantly different $(\mathrm{P}<0.05)$

* No significant differences of percentages of fat, protein among treatments 
Table (5): Blood urea (mg/dl), total protein (g/dl), alkaline phosphatase (units/l) and liver enzymes (units/l) of lactating cows fed experimental total mixed rations (TMR) with or without Bentonite and Zeolite additives

\begin{tabular}{|c|c|c|c|c|}
\hline Item & Ration 1 & Ration 2 & Ration 3 & Normal range \\
\hline Urea (mg/dl) & $28 \pm 0.58$ & $26 \pm 0.89$ & $23 \pm 0.58$ & $6-27$ \\
\hline Total protein (g/dl) & $8.5 \pm 0.73$ & $8.1 \pm 0.32$ & $8.4 \pm 0.26$ & $5.7-8.1$ \\
\hline Alkaline phosphatase (units/l) & $136 \pm 2.60$ & $91 \pm 2.02$ & $105 \pm 3.18$ & $0-500$ \\
\hline ALT (units/l) & $23 \pm 0.89$ & $23 \pm 0.88$ & $26 \pm 0.98$ & $11-40$ \\
\hline AST (units/l) & $84 \pm 1.73$ & $91 \pm 1.53$ & $85 \pm 1.76$ & $78-132$ \\
\hline
\end{tabular}

All values of blood urea, Alkaline phosphatase, AST and ALT enzymes in all groups in this study are shown in Table (5) and lie within the normal levels as explained by Jackson and Cockcroft (2002).

\section{CONCLUSION}

From the results obtained in this study it could be concluded that the adding Bentonite $(70 \mathrm{~g}$ Bentonite/cow/day) in rations of high yielding lactating cows led to improved digestibility, feed conversion and increased milk and fat yields.

\section{REFERENCES}

AOAC (1995). Association of Official Analytical Chemists Official Methods of Analysis, $16^{\text {th }}$ ED. Washington, D.C, USA.

Duncan, D.B. (1955). Multiple range and multiple Ftest. Biometrics, 11: 1- 42.

El-Saadany, S. A., T. I. El-Monayer, A. M. Zeid and M. A. Boraei (2003). Effect of feeding different rations with or without Bentonite on the performance of growing lambs. Egyptian J. Nutrition and feeds 4 (Special issue): 11811190.

Fisher, L. J. and V. G. Mackay (1983). The investigation of sodium bicarbonate or Bentonite as supplements in silages fed to lactating cows. Canadian journal of animal science, 63(4), 939-947.

Ghoniem, A. H., E. A. El-Bltagy and A. A. Abdou (2018). Effect of Supplementation Dry Yeast or Bentonite and their Combination as Feed Additives on Productive Performance of Lactating Buffalos. Journal of Animal and Poultry Production, 9(11): 423-431.

Ibrahim, A. K. M. (2012). Effect of clay mineral on utilization of some mineral elements in ruminant feeding. Ph. D. Thesis, Fac. Agaic. Zagazig Univ.

Jackson, G. G. and D. Cockcroft (2002). Clinical Examination of Farm Animals, Blackwell Science Ltd, Oxford, UK
Jiang, Y., I. M. Ogunade, D. H. Kim, X. Li, A. A. PechCervantes, K. G. Arriola and D. Vyas (2018). Effect of adding clay with or without a Saccharomyces cerevisiae fermentation product on the health and performance of lactating dairy cows challenged with dietary aflatoxin B1. Journal of dairy science, 101(4): 3008-3020.

Kirovski, D., M. Adamovic, M. Radivojevic, H. Samanc, I. Vujanac, R. Prodanovic and Z. Sladojevic (2015). Effects of Bentonite on weight gain, feed consumption, blood metabolites and ruminal protozoa in dairy calves. Animal Nutrition and Feed Technology, 15(1): 11-20.

Nadziakiewicza, M., S. Kehoe and P. Micek (2019). Physico-chemical properties of clay minerals and their use as a health promoting feed additive. Animals, 9(10): 714.

National Research Council (NRC) (2001). Nutrient Requirements of Dairy Cattle. $7^{\text {th }}$ Rev. Ed. National Academy of Sciences, Washington, D.C.

Pasha, T. N., M. U. Farooq, F. M. Khattak, M. A. Jabbar and A. D. Khan (2007). Effectiveness of sodium Bentonite and two commercial products as aflatoxin absorbents in diets for broiler chickens. Animal Feed Science and Technology, 132(1-2): 103-110.

Rindsig, R. B., L. H. Schultz and G. E. Shook (1969). Effects of the addition of Bentonite to highgrain dairy rations which depress milk fat percentage. Journal of Dairy Science, 52(11): 1770-1775.

SPSS (2011). SPSS Statistics for Windows, Version 20.0. Armonk, NY, USA: IBM Corp.

Van Keulen, J. Y. B. A. and B. A. Young (1977). Evaluation of acid-insoluble ash as a natural marker in ruminant digestibility studies. Journal of Animal Science, 44(2): 282-287.

Young, D. S. and R. B. Friedman (2001). Effects of disease on clinical laboratory tests (Vol. 1). Amer Assn for Clinical Chemistry. 


\title{
تأثثر إضافة البنتونيت علي محصول اللبن و تركيب اللبن و معامل الهضم و القيم الغذائية في أبقار الهولستين
}

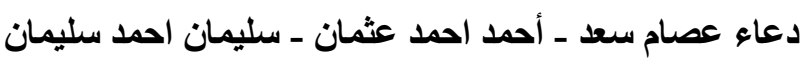

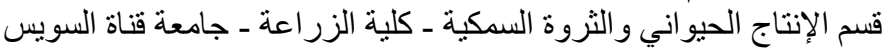

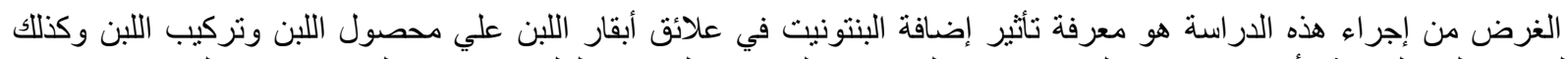

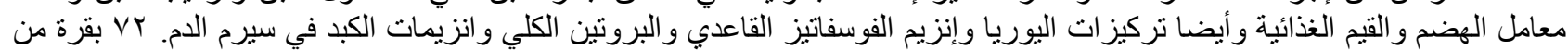

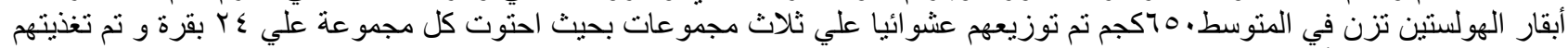

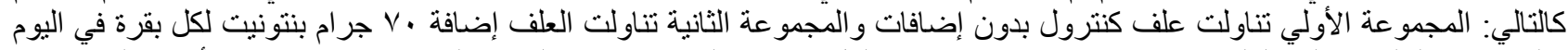

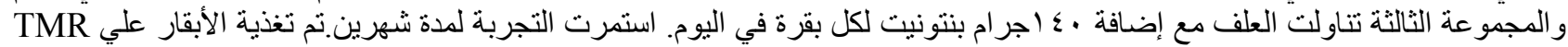

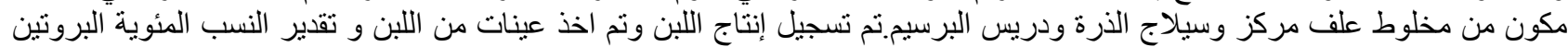

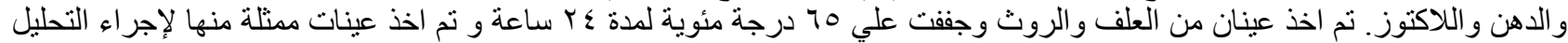

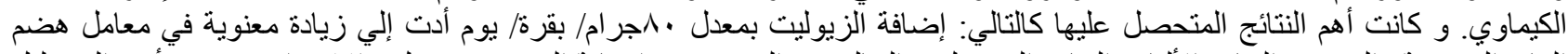

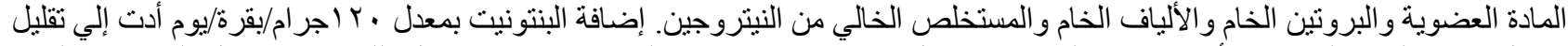

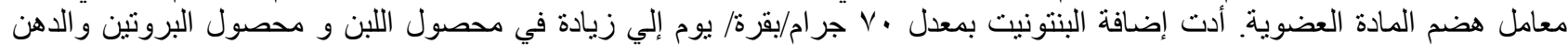
و اللاكتوز . وبشكل عام ظلت تركيز ات اليورياو الفوسفاتيز القاعدي و البروتين الكلي و إنزيمات الكبد في سيرم الدم ضمن المستويات الطبيعية. 